\title{
PEMBINAAN KEMANDIRIAN DALAM MEMBANGUN KEPERCAYAAN DIRI NARAPIDANA DI MASA PANDEMI COVID-19
}

Yuliana Novitasari

\author{
Manajemen Pemasyarakatan, Politeknik Ilmu Pemasyarakatan, yuliananovita036@gmail.com
}

\begin{abstract}
Currently the world, including Indonesia, has been shocked by the emergence of a pandemic, namely the Covid-19 pandemic which was first discovered in Wuhan, China. The emergence of this pandemic has had a huge impact on the world economy. Especially with the implementation of the correctional system in Indonesia, namely the process of fostering independence. This study aims to determine what self-reliance coaching officers of the Class I Rutan Surakarta can do to build confidence in prisoners during the Covid-19 pandemic. The method used is qualitative research methods using various sources of this data by conducting interviews, documentation, and literature studies to obtain valid information. The result of this research is that the self-reliance development in the Class I Rutan Surakarta continues even though it is ineffective due to the Covid-19 pandemic. Self-reliance development that is still ongoing during the Covid-19 pandemic includes self-sufficiency in sewing, screen printing, and handicrafts. The officer fulfills the basic rights of the prisoner and conducts an assessment in determining the type of coaching that is tailored to the interests and talents so that later the prisoners are able to actualize themselves directly in the community with full self-confidence.
\end{abstract}

ARTICLE INFO Keywords:

self-confidence; pandemic; self-reliance building; prison

Cite this paper:

Novitasari, Y. (2021).

Pembinaan Kemandirian

Dalam Membangun

Kepercayaan Diri

Narapidana Di Masa

Pandemi Covid-19. Widya

Yuridika: Jurnal Hukum, $4(2)$.

Scope Article

Law and Society

\section{PENDAHULUAN}

Negara Indonesia telah menjadi negara yang menjunjung tinggi keadilan dihadapan hukum dalam upaya menyelesaikan permasalahan yang terjadi. Negara Indonesia menganut teori kedaulatan hukum dan kedaulatan rakyat yang berlandaskan pancasila dan Bhinneka Tunggal Ika (Nursalam, 2016 \& Fallis, 2013). Sehingga dengan berlandaskan pancasila, hukum yang ditegakkan telah bersumber dari nilai-nilai masyarakat Indonesia. Sebagai Negara hukum, Indonesia telah dilengkapi oleh sistem peradilan pidana untuk menyelesaikan permasalahan yang berkaitan dengan hukum saat ini. Sistem peradilan pidana di Indonesia terdiri dari instansi kepolisian sebagai pihak yang berwenang melakukan penyidikan tindak pidana, kejaksaan sebagai pihak yang melakukan penuntutan, pengadilan sebagai instansi yang berwenang mengadili tindak pidana, dan pemasyarakatan sebagai instansi terakhir dalam proses sistem peradilan pidana yang bertugas menjalankan segala putusan yang telah ditetapkan oleh pengadilan. Dengan demikian, pemasyarakatan memiliki tugas penting dalam memberikan pelayanan yang terbaik bagi terpidana selama terpidana telah menjadi tanggung jawab lembaga pemasyarakatan (Sistem et al., n.d.). Tugas pemasyarakatan antara lain memberikan perawatan tahanan, pembinaan narapidana, dan 
pembimbingan klien dimana pemasyarakatan memiliki tanggung jawab besar dalam mendidik narapidana untuk kembali ke masyarakat secara utuh. Berdasarkan penjabaran UU nomor 12 tahun 1995 tentang pemasyarakatan, tujuan yang diharapkan dari sistem pemasyarakatan telah dijelaskan secara rinci yang pada intinya pembinaan yang diberikan bertujuan untuk meningkatkan kualitas diri warga binaan pemasyarakatan, adanya pembinaan tersebut diharapkan warga binaan dapat menyadari kesalahan yang telah mereka lakukan, warga binaan juga dapat memperbaiki diri dan kembali ke jalan yang benar, warga binaan diharapkan tidak mengulangi tindak kejahatan sehingga masyarakat luar dapat menerima kembali, warga binaan dapat aktif berperan dalam pembangunan nasional, serta dapat hidup dengan sebaik-baiknya dengan penuh bertanggung jawab (Equatora, 2018). Sistem pemasyarakatan memiliki prinsip yang sangat mulia yaitu memanusiakan manusia dengan cara memberikan pelayanan yang terbaik bagi narapidana. Narapidana diberikan pelayanan seperti pelayanan kesehatan, perawatan tahanan, mendapatkan makanan, memperoleh pembinaan, dan pemenuhan haknya meski di dalam lembaga pemasyarakatan. Akan tetapi, harapan yang diinginkan dari sistem pemasyarakatan belum dapat terwujud karena banyak ditemukan pelaku tindak pidana kejahatan yang beraksi di Indonesia merupakan mantan narapidana yang telah selesai menjalani masa pidana (Setiawan \& Sakti, 2019). Sebagai contoh kasus yang terjadi di Indonesia yaitu tindak pidana pengulangan di Jawa Timur yaitu penangkapan komplotoan yang melakukan perampokan nasabah bank dimana pelaku merupakan mantan narapidana dengan kasus yang sama (Madia, 2018). Pencurian sepeda motor yang terjadi di Jakarta dimana kedua pelaku merupakan eks narapidana yang telah selesai menjalani hukuman kasus perampokan bersenjata dan pembunuhan (Hamanongan, 2018). Selain itu juga terjadi kasus pengulangan tindak pidana di tiga lokasi yang terjadi di Semarang, pelaku melakukan aksinya selang 10 hari usai menjalani hukuman di pemasyarakatan ("Hari bebas residivis kembali beraksi 3 kali", 2017).

Terlebih dengan munculnya pandemi yang menggemparkan seluruh dunia yaitu pandemi covid-19 yang ditemukan pertama kali di daerah Wuhan Cina. Seluruh masyarakat dunia khawatir dengan adanya wabah tersebut, terlebih dengan adanya pengumuman yang dikeluarkan oleh WHO bahwa pandemi yang ada saat ini merupakan sebagai pandemi global (Dong et al., 2020). Pada awal tahun 2020, Negara Indonesia ikut merasakan wabah pandemi covid-19 yang juga telah dialami hampir 120 negara di seluruh dunia (Dida et al., 2021). Dampak yang ditimbulkan dari wabah ini sangat luar biasa, khususnya di bidang perekonomian, Indonesia yang menurun drastis dilihat dari pertumbuhan ekonomi Indonesia sebelum pandemi diperkirakan mencapai 5,3\% namun akibat pandemi terjadi kemerosotan hingga dibawah 2\% (Hadiwardoyo et al., n.d., 2020). Banyak pengusaha besar, pedagang pasar, pelaku industri rumahan, dan pegawai swasta yang mengalami dampak merosotnya penghasilan. Selain itu, banyak buruh yang di PHK dari berbagai macam perusahaan karena perusahaan tersebut terancam mengalami kebangkrutan. Telah tercatat sebanyak 114.340 perusahaan yang melakukan pemberhentian kerja dan tidak mempekerjakan para pekerja swasta dengan jumlah sebanyak 1.943 .916 orang atau $77 \%$ sektor formal dan 23\% merupakan sektor informal (Kemnaker, 2020).

Adanya pandemi Covid-19 juga berdampak di lingkungan pemasyarakatan sebagai akibat dari menurunnya perekonomian Indonesia. Hal ini ditunjukkan dengan banyaknya masyarakat Indonesia yang terkena PHK dan banyak pelaku usaha kecil mengalami kebangkrutan, berimbas pada kondisi di lingkungan pemasyarakatan bahwa banyak narapidana yang merasa khawatir akan proses pembinaan yang diberikan kepada mereka karena pembinaan yang diberikan bertujuan agar narapidana dapat menjalankan kehidupannya secara mandiri dan tidak mengharapkan bantuan dari orang lain. Pembinaan yang diberikan masih sebatas pembinaan kemandirian yang belum mengarah ke perekonomian kreatif di masa pandemi covid-19. Pembinaan yang sudah ada selama ini belum berjalan secara optimal mengingat kondisi lembaga pemasyarakatan dan rumah 
tahanan yang overcapacity. Dengan keadaan tersebut, Menteri Hukum dan Hak Asasi Manusia memberikan kebijakan untuk mengeluarkan narapidana sebagai proses asimilasi dimasa pandemi covid-19 dengan tujuan untuk dapat menerapkan protokol kesehatan dan untuk menekan persebaran covid-19 yang ada di lembaga pemasyarakatan maupun rumah tahanan negara. Kebijakan yang ditetapkan oleh Menteri Hukum dan Hak Asasi Manusia di rasa sangat tepat dan apabila terlambat mengambil tindakan tersebut maka dapat dipastikan bahwa rumah tahanan negara dan lembaga lemasyarakatan menjadi salah satu penyumbang terbanyak kasus covid-19 di Indonesia. Selain untuk mencegah persebaran covid-19 di lembaga pemasyarakatan maupun rumah tahanan negara, kebijakan tersebut juga bertujuan untuk mengoptimalkan pembinaan kemandirian yang diberikan oleh petugas agar pembinaan yang diberikan dapat berjalan secara efektif mengingat jumlah penghuni lembaga pemasyarakatan maupun rumah tahanan negara sudah mengalami penurunan dengan diterapkannya kebijakan tersebut. Pemberian pembinaan khususnya pembinaan kemandirian kepada warga binaan di masa pandemi covid-19 bertujuan untuk menyiapkan masyarakat yang siap kerja di lingkungan masyarakat secara utuh. Akan tetapi, pembinaan yang diberikan belum disesuaikan dengan kondisi saat ini dimana adanya pandemi covid-19 mengakibatkan masyarakat yang memiliki usaha kecil maupun menengah terus mengalami kebangkrutan. Banyaknya masyarakat yang kehilangan pekerjaannya karena covid-19 maka pembinaan kemandirian yang diberikan kepada warga binaan harus berdasarkan prinsip pada ekonomi kreatif agar ketika sudah selesai menjalani masa pidana mereka mampu mengambil peluang dan dapat bersaing dengan masyarakat lainnya. Pemberian pembinaan kemandirian kepada warga binaan diharapkan juga dapat mengembangkan bakat yang mereka miliki agar tetap berkarya meski di dalam lembaga pemasyarakatan. Pembekalan pembinaan kemandirian kepada narapidana tentu dapat memberikan dorongan kepada narapidana untuk berusaha meningkatkan kualitas diri agar dapat mengembangkan diri kearah yang lebih baik (Aisharahma \& Irhandayaningsih, 2020). Dengan adanya pembekalan pembinaan kemandirian diharapkan narapidana dapat meningkatkan kepercayaan diri sehingga mereka mampu menjalani hidup di lingkungan yang sebenarnya tanpa ada rasa beban moral atas kesalahan yang pernah mereka lakukan (Saleh \& Arifin, 2017). Dengan membentuk kepercayaan diri yang tinggi dalam diri narapidana, maka diharapkan narapidana tersebut mampu bertahan hidup di lingkungan masyarakat nantinya dan dapat menerapkan ketrampilan yang diperoleh untuk memenuhi kebutuhan mereka danpa merepotkan orang lain. Selain itu, dalam membangun kepercayaan diri, narapidana harus didukung dengan sikap optimis agar mampu bersaing dengan orang lain dan mampu membuktikan bahwa seorang yang pernah salah jalan juga mampu kembali ke jalan yang benar dan mampu mengembangkan diri mereka untuk meraih masa depan (Fitri et al., 2018). Maka dari itu, pembahasan ini dimaksudkan untuk mengetahui Pembekalan Pembinaan Kemandirian Dalam Membangun Kepercayaan Diri Narapidana Dimasa Pandemi Covid-19.

\section{METODE}

Berdasarkan penelitian yang dilakukan oleh penulis, maka metode yang digunakan yaitu metode pendekatan penelitian kualitatif dimana dalam penelitian ini peneliti harus dilandaskan pada teori yang saling keterkaitan dengan berbagai masalah yang sedang diteliti untuk menemukan penyelesaian masalah. Metode penelitian kualitatif adalah salah satu cara yang digunakan untuk mencari dan memberi makna oleh sejumlah orang atau kelompok mengenai masalah social atau kemanusiaan (creswell, 2016). Jenis metode penelitian yang dipilih untuk mendukung keberlangsungan penelitian yaitu dengan desain deskriptif analisis.

Peneliti menggunakan beragam sumber data ini dengan melakukan wawancara, dokumentasi, dan studi literatur untuk memperoleh informasi yang valid daripada hanya bersumber dari satu sumber data saja. Setelah mengumpulkan data dan informasi, peneliti melakukan review dari semua data, mengartikan maksud-maksud, dan mengolah data 
dengan melakukan triangulasi data sehingga peneliti dapat memperoleh hasil yang objektif sesuai dengan yang diharapkan.

Menurut creswell, 2016 bahwa wawancara merupakan cara memperoleh informasi melalui interaksi berhadap-hadapan, telepon, focus group, dan atau melalui email. Teknik wawancara ini diharapkan peneliti memperoleh informasi melalui pertanyaan-pertanyaan sesuai dengan pedoman wawancara yang sudah di buat sebelumnya. Dokumentasi merupakan teknik pengumpulan data dengan mengambil gambar keadaan yang dibutuhkan sebagai data penelitian guna mempeerjelaskan kondisi yang ada. Teknik pengumpulan data melalui studi literature digunakan untuk memperoleh informasi melalui sumber bacaan seperti data dari SDP, sumber bacaan yang diperoleh dari petugas di lembaga pemasyarakatan, maupun sumber bacaan yang disimpan di tiap-tiap bagian lembaga pemasyarakatan terkait pembinaan kemandirian yang dapat dilakukan di lembaga pemasyarakatan.

Penelitian ini tentang macam-macam pembinan kemandirian yang dapat dilakukan di unit pelaksana teknis pemasyarakatan dengan mempertimbangkan kondisi perekonomian dunia yang terus menurun akibat pandemi Covid-19 di Rutan Kelas I Surakarta.

\section{HASIL DAN PEMBAHASAN}

Pembinaan merupakan suatu proses untuk belajar memperoleh sesuatu dengan cara meninggalkan hal-hal yang melekat dalam diri seseorang dengan tujuan untuk membantu menjalani proses belajar tersebut dengan mengoreksi dan mengembangkan wawasan dan kemampuan dan digunakan untuk memperoleh wawasan yang baru dalam menggapai citacita, yang telah berjalan saat ini secara efektif (balitbang, 2019). Pada umumnya, pembinaan di bagi menjadi pembinaan kemandirian dan pembinaan kerohanian. Dalam penelitian ini, peneliti memfokuskan dalam melakukan pembahasan mengenai pembinaan kemandirian. Pembinaan kemandirian merupakan suatu pelatihan yang diberikan kepada narapidana dalam mengasah kemampuan yang mereka miliki dalam menyiapkan diri untuk dapat meningkatkan kemandirian hidup mereka sehingga ketika sudah selesai menjalani masa pembinaan mereka dapat mengimplementasikan kemampuan tersebut dalam memenuhi kebutuhan mereka sehari-hari. Program-program pembinaan kemandirian yang diberikan kepada narapidana (Sujatno, 2004), diantaranya yaitu: yang pertama, pembinaan keterampilan dalam mendukung berbagai usaha mandiri narapidana, seperti halnya yaitu pembinaan kerajinan tangan, pelaksanaan industri dalam rumah tangga, pelatihan reparasi mesin serta reparasi alat-alat elektronika. Kedua, pembinaan keterampilan dalam mendukung usaha industri kecil, sebagai contoh yaitu pembinaan dengan mengelola bahan mentah dari sektor pertanian dan bahan alam menjadi bahan setengah jadi dan menjadi bahan jadi. Ketiga yaitu pembinaan keterampilan yang dapat diberikan berdasarkan minat dan bakat yang dimiliki oleh narapidana. keempat merupakan pembinaan keterampilan yang digunakan untuk menunjang pelaksanaan usaha industri maupun kegiatan pertanian (perkebunan) dengan teknologi madya atau teknologi tinggi, seperti dalam industri kulit dan pabrik tekstil.

Kepercayaan diri adalah suatu perasaan positif yang dimiliki oleh seseorang dapat berupa adanya suatu rasa keyakinan dan kepercayaan terhadap keahlian dan potensi yang ada dalam diri orang tersebut, serta dengan adanya keahlian dan potensi yang ada, orang tersebut merasa dapat menyelesaikan semua tugas dengan lancar dan untuk mencapai citacita hidup mereka (Idrus dan Rohmiati, 2011). Berdasarkan pendapat Lauster, 2011 yang mengemukakan mengenai aspek-aspek yang ada dalam kepercayaan diri yaitu: Keyakinan terhadap kemampuan atau keahlian diri merupakan adanya sikap yang baik dalam suatu individu tentang pandangan bahwa dirinya mengerti tentang apa yang akan mereka dilakukannya; Optimis adalah bentuk sikap positif yang dimiliki seseorang dengan pandangan yang baik dalam menghadapi kejadian terhadap diri, harapan yang ada, dan kemampuan yang mereka mereka; Objektif adalah rasa percaya diri seseorang dalam memandang berbagai permasalahan yang disesuaikan dengan kebenaran yang 
sesungguhnya, bukan hanya berdasarkan pandangan subjektif atau berdasarkan pemikiran diri mereka sendiri; Bertanggungjawab merupakan kesediaan individu dalam memikul semua permasalahan yang telah menjadi tanggung jawab individu tersebut; Rasional merupakan pandangan seseorang dalam melihat permasalahan sesuai pemikiran yang dapat diterima oleh orang lain dan disesuaikan dengan kondisi yang ada saat ini.

Berdasarkan Permenkumham nomor 6 tahun 2013 tentang Tata Tertib Lembaga Pemasyarakatan dan Rumah Tahanan Negara, pengertian dari rumah tahanan Negara adalah suatu tempat untuk menempatkan tersangka atau terdakwa ditahan selama proses penyidikan, penuntutan, dan pemeriksaan di sidang pengadilan. Rutan memiliki fungsi yaitu menjadi tempat perawatan tahanan. Akan tetapi, dengan adanya overcapacity mengakibatkan rutan diperbolehkan melaksanakan pembinaan bagi narapidana yang berada di rutan. Meskipun pembinaan yang ada di rutan tidak dapat berjalan dengan baik seperti yang ada di lapas, akan tetapi pembinaan di rutan di desain semirip mungkin dengan bentuk pelaksanaan pembinaan di lapas pada umumnya.

Pembinaan kemandirian yang dilakukan di Rutan Kelas I Surakarta sudah berjalan dalam kurun waktu yang cukup lama. Sehingga Rutan Kelas I Surakarta memiliki macammacam pembinaan kemandirian yang masih terus berjalan hingga saat ini. Meskipun berbagai Negara termasuk Indonesia mengalami pandemi Covid-19 yang cukup lama, pembinaan kemandirian di dalam Rutan tetap terus berjalan dengan menerapkan protokol kesehatan yang ketat.

\section{Pembinaan kemandirian di Rutan Kelas I Surakarta}

Pembinaan kemandirian yang diterapkan di Rutan Kelas I Surakarta dimasa pandemi Covid-19, antara lain yang pertama yaitu pembinaan kemandirian menjahit. Berdasarkan hasil wawancara, pembinaan menjahit telah dilaksanakan di rutan sudah sejak lama. Pembinaan menjahit sudah semakin berkembang dimana saat ini Rutan Kelas I Surakarta bekerja sama dengan pihak ketiga dalam memberikan pelatihan kepada narapidana. pihak ketiga yang bekerja sama dengan rutan yaitu BLK dengan memberikan pelatihan menjahit kepada narapidana dengan menerapkan protokol kesehatan. Tujuan adanya pembinaan ini yaitu narapidana dapat mengasah bakat mereka dan diharapkan dengan adanya pembinaan menjahit narapidana dapat mengimplementasikannya ketika sudah selesai menjalani masa pidana untuk memenuhi kebutuhan mereka secara mandiri. Kedua, Pembinaan kemandirian sablon, pembinaan sablon diperuntukkan bagi narapidana laki-laki yang ada di Rutan Kelas I Surakarta. Pelatihan sablon biasanya dilakukan dengan kehati-hatian untuk memperoleh hasil yang memuaskan. Para narapidana biasanya juga mengasah keterampilan dengan menerima pesanan dari para petugas yang ingin dibuatkan kaos sendiri. Selain itu, pembinaan sablon di Rutan Kelas I Surakarta juga memiliki pasar online melalui sosial media, sehingga narapidana dapat mengasah keterampilan mereka dengan memantau pesanan tersebut. Ketiga, pembinaan kerajinan tangan, pembinaan di Rutan Kelas I Surakarta memiliki berbagai macam pembinaan kerajinan tangan seperti merajut, membuat kerajinan dari kayu, dan lainnya. Pembinan merajut biasanya dilakukan oleh para narapidana wanita dan pembinaan kerajinan dari kayu yaitu membuat kapal biasanya dilakukan oleh narapidana laki-laki. Kerajinan tangan yang ada di Rutan Kelas I Surakarta harus dilakukan dengan teliti karena dilakukan secara detail. kerajinan tersebut biasanya dipamerkan kepada pengunjung agar dapat melihat hasil karya WBP di dalam rutan. Banyak pengunjung yang terpukau melihat hasil karya para narapidana karena pameran tersebut dapat merubah persepsi masyarakat terhadap rutan maupun lapas sehingga adanya persepsi yang positif dari masyarakat diharapkan dapat menumbuhkan rasa percaya diri bagi para WBP untuk bersosialisasi langsung dengan masyarakat secara utuh.

\section{Analisis pembinaan kemandirian dalam membangun kepercayaan diri narapidana}


Pembinaan kemandirian yang diberikan di Rutan Kelas I Surakarta sudah sangat bermacam-macam meskipun bukan tugas utama rutan dalam memberikan pembinaan. Narapidana yang mengikuti pembinaan kemandirian tentu memiliki kepribadian yang berbeda-beda. Sehingga petugas perlu menggali informasi untuk mengetahui rasa kepercayaan diri narapidana selama mengikuti pembinaan di Rutan Kelas I Surakarta. Seseorang yang memiliki rasa percaya diri yang tinggi biasanya memiliki faktor-faktor yang mendukung dalam diri mereka begitu juga dengan sebaliknya. Narapidana juga akan memiliki rasa percaya diri yang tinggi apabila factor pendukung yang mereka perlukan telah terpenuhi. faktor-faktor yang dapat mempengaruhi kepercayaan diri antara lain yang pertama adalah kebutuhan dasar atau fisiologis. Berdasarkan hasil wawancara kepada narapidana, kebutuhan dasar narapidana yang mengikuti pembinaan kemandirian seperti sandang, pangan, dan papan sudah terpenuhi. Setiap narapidana mendapatkan seragam pembinaan kemandirian, mendapatkan perawatan makanan yang sama, dan fasilitas pembinaan yang telah memenuhi. Selain itu, para narapidana juga tetap boleh mendapatkan kiriman dari keluarga mereka meskipun di masa pandemic covid-19. Kedua, kebutuhan rasa aman bagi narapidana. berdasarkan wawancara narapidana, para narapidan yang mengikuti pembinaan kemandirian merasa aman dan terlindungi karena pembinaan kemandirian di Rutan Kelas I Surakarta setah menerapkan SOP yang ketat, penerapan protocol kesehatan, terdapat instruktur atau pelatih, dan lokasi tempat pembinaan berdekatan dengan poliklinik rutan. Sehingga para narapidana dapat melaksanakan pelatihan tanpa ada rasa takut adanya kecelakaan kerja. Ketiga, kebutuhan kasih sayang dan saling memiliki antar narapidana maupun petugas. Para narapidana saat di wawancara menjelaskan tentang adanya rasa saling peduli khususnya di bagian pembinaan kemandirian. Hal ini di dorong karena para narapidana menghabiskan waktu yang cukup lama di tempat yang sama sehingga mereka saling merasa saling memiliki. Kasih sayang yang diberikan juga tidak hanya berasal dari sesama narapidana, mereka juga sering mendapat kiriman makanan dari keluarga mereka sehingga kasih saying dari keluarga di rumah juga masih terjalin. Biasanya mereka akan saling berbagi apabila salah satu dari narapidana dibagian pembinaan kemandirian mendapat kiriman makanan. Adanya rasa kasih sayang dan saling memiliki dapat menumbuhkan rasa percaya diri narapidana karena mendapat dukungan penuh dari lingkungan sekitar. Keempat, kebutuhan yang keempat yaitu adanya rasa saling menghargai. Pernyataan dari hasil observasi, dapat dijelaskan bahwa setiap narapidana yang mengikuti pembinaan kemandirian saling menghargai. Sebagai contoh saat narapidana laki-laki sedang melaksanakan ibadah sholat jumat, maka yang berjaga di ruang pembinaan adalah narapidana perempuan. Selain itu juga mereka selalu menerapkan senyum, sapa, salam kepada siapapun yang mereka temui. Sehingga tidak ada perbedaan perlakuan baik kepada sesama narapidana maupun kepada petugas. Selama pandemi covid-19 berlangsung, para narapidana menerapkan protokol kesehatan dengan baik untuk saling melindungi akan bahaya virus tersebut. Kegiatan sehari-hari di Rutan Kelas I Surakarta juga mendidik narapidana untuk saling menghargai meskipun berbeda agama. Bagi narapidana tia-tiap agama diberikan jadwal pembinaan kerohanian dan saling menghargai apabila salah satu agama sedang menjalankan ibadah. Kelima, yaitu kebutuhan dasar aktualisasi diri. Aktualisasi diri merupakan seseorang yang dapat menggunakan dan memanfaatkan dengan penuh berupa bakat, kapasitas yang dimiliki, potensi-potensi yang ada dalam diri orang tersebut untuk memenuhi kebutuhan diri. Seseorang yang sudah memiliki 4 kebutuhan dasar lainnya, maka puncak teratas yang harus dicapai yaitu kebutuhan dalam mengaktualisasi diri. Narapidana yang ada di Rutan Kelas I Surakarta dalam menentukan jenis pembinaan yang akan mereka ikuti harus dilakukan assessment oleh petugas. Petugas akan menyesuaikan kemampuan, bakat, dan minat yang ada dalam narapidana tersebut. Hal ini bertujuan agar dalam mengikuti pembinaan nantinya, narapidana dapat mengikuti tanpa adanya paksaan, sesuai dengan kemampuan dan bakat mereka, dan dapat mengikuti dengan tekun. Oleh karena itu, narapidana yang mengikuti pembinaan kemandirian saat ini sudah melalui tahapan assesmen sehingga diharapkan narapidana dapat mengikuti pembinaan 
dengan baik. Adanya pelatihan yang diberikan kepada narapidana bertujuan agar nantinya saat sudah selesai menjalani masa pidana, mereka dapat mengimplementasikan bekal yang sudah diberikan di dalam rutan. Implementasi tersebut dilakukan tanpa adanya paksaan dari orang lain, dilakukan dengan senang hati, dan dapat mencukupi kebutuhan secara mandiri.

\section{Faktor pendukung dan penghambat pembinaan kemandirian di Rutan Kelas I Surakarta}

Rutan Kelas I Surakarta merupakan tempat berkumpulnya para tahanan baik tahanan kepolisian, kejaksaan, maupun pengadilan sebelum mendapat putusan yang tetap dari pengadilan. Akan tetapi, rutan khususnya Rutan Kelas I Surakarta juga menjalankan program pembinaan karena adanya overcapacity yang hampir terjadi di semua lapas maupun rutan di Indonesia. Rutan Kelas I Surakarta memiliki faktor pendukung dalam menjalankan program pembinaan kemandirian meskipun fungsi utama rutan yaitu menjalankan perawatan tahanan. Faktor pendukung Rutan Kelas I Surakarta antara lain lokasi rutan yang berada di central karesidenan Surakarta sehingga seluruh perekonomian terpusat di Kota Surakarta. Sehingga dalam menjalankan pembinaan dengan pihak ketiga, rutan sangat diuntungkan karena mudah mendatangkan pihak ketiga karena lokasi yang strategis. Selain itu, narapidana yang mengikuti pembinaan kemandirian di Rutan Kelas I Surakarta hampir keseluruhan merupakan orang Surakarta. Dalam mendukung berjalannya program pembinaan kemandirian, perlu adanya dukungan dari keluarga untuk memberi dorongan agar mau mengikuti pembinaan dengan disiplin dan singguh-sungguh. Berdasarkan hasil wawancara dengan narapidana, fasilitas sarana dan prasarana pembinaan kemandirian yang disediakan oleh Rutan Kelas I Surakarta juga sangat memenuhi. baik dari bahan mentah maupun dari segi peralatan dalam menunjang pelatihan pembinaan kemandirian. Adanya faktor-faktor pendukung tersebut, para narapidana yang mengikuti pembinaan kemandirian akan merasa nyaman dan kebutuhan yang mereka perlukan dalam meningkatkan rasa percaya diri narapidana dapat terpenuhi.

Berdasarkan observasi lapangan selain faktor pendukung, terdapat juga faktor penghambat dalam melaksanakan proses pembinaan kemandirian di Rutan Kelas I Surakarta. Salah satu faktor penghambat yaitu fungsi rutan pada awalnya yaitu perawatan beralih ke menjalankan pembinan dengan luas rutan yang relatif sempit. Sehingga proses pembinaan kemandirian tidak berjalan secara efektif. Faktor penghambat lain yaitu rendahnya motivasi dari narapidana dalam mengikuti pembinaan kemandirian. Rendahnya motivasi tersebut disebabkan oleh beberapa hal seperti adanya rasa kurang percaya diri, tidak semangat, takut, dan merasa terkucilkan. Narapidana yang memiliki motivasi yang rendah biasanya akan mudah mengalami gangguan mental karena mereka tidak mudah menyesuaikan diri dengan lingkungan yang baru sehingga mereka tidak dapat bertahan dalam lingkungan rutan.

\section{DISKUSI}

Adanya pandemi covid-19 yang belum juga berakhir hingga saat ini, mengakibatkan pembinaan di rutan khususnya Rutan Kelas I Surakarta tidak berjalan sesuai harapan. Pembinaan yang seharusnya dapat dilakukan di luar rutan harus dialihkan dengan melaksanakan pembinaan di dalam rutan. Selain itu, pembinaan yang seharusnya mendatangkan pelatih dari luar harus ditunda terlebih dahulu dengan tujuan untuk mencegah persebaran covid-19 di rutan. Mengingat jumlah penghuni rutan yang overcapacity, maka dilakukan pencegahan-pencegahan seperti hal tersebut untuk menghindari penambahan kasus yang semakin banyak. Perlu diingat apabila pandemic covid-19 menyerang unit pelaksana teknis di pemasyarakatan maka dapat dipastikan rutan dan lapas menjadi penyumbang yang paling banyak karena jumlah tahanan dan narapidana yang sangat banyak. Sehingga perlu adanya alternative-alternatif pembinaan kemandirian 
yang tetap dapat dilaksanakan di dalam rutan meskipun pandemi covid-19 masih belum berakhir.

Meskipun pembinaan kemandirian yang seharusnya dilaksanakan di luar rutan akan tetapi dialihkan di dalam rutan, diharapkan para narapidana tetap mengikuti program yang diberikan dengan penuh tanggung jawab. Pembinaan kemandirian yang dapat dilakukan di rutan selama adanya pandemi covid-19 antara lain yaitu pembinaan kemandirian memasak, menjahit, kerajinan tangan, dan sablon.

Pembinaan kemandirian memasak tetap dapat dilaksanakan di dalam rutan meskipun dimasa pandemi covid-19 saat ini. Berdasarkan hasil observasi, pembinaan memasak dapat dilaksanakan dengan memanfaatkan bahan mentah yang sudah ada. Biasanya yang mengikuti pembinaan memasak yaitu narapidana perempuan. Pembinaan memasak dilakukan setiap hari dengan mencoba berbagai macam resep makanan untuk diperjualbelikan di dalam rutan. Para narapidana wanita yang mengikuti pembinaan memasak membuat masakan seperti donat, risol mayonise, dan masakan lainnya. Pembinaan kemandirian ini diharapkan dapat meningkatkan kemampuan memasak para narapidana wanita. Semakin meningkat kemampuan memasak maka diharapkan narapidana yang sudah selesai menjalani masa pembinaan dapat menerapkan kemampuan yang mereka miliki dengan membuat usaha makanan.

Pembinaan kemandirian menjahit, pembinaan ini dapat dilaksanakan di Rutan Kelas I Surakarta dimasa pandemi covid-19. Melihat dari observasi lapangan, ditemukan bahwa terdapat narapidana laki-laki yang sudah memiliki kemampuan menjahit sebelum masuk rutan. Sehingga dengan adanya narapidana tersebut, pembinaan menjahit di rutan dapat berjalan hingga saat ini. Meskipun tidak dapat mendatangkan pelatih dari luar, para narapidana dapat belajar langsung dari narapidana lain yang memiliki keahlian dalam menjahit. Setelah 1 tahun pandemi covid-19 berlangsung, Rutan Kelas I Surakarta melakukan kerjasama dengan pihak ketiga yaitu BLK. Kerjasama ini dilakukan untuk memberikan pelatihan menjahit kepada narapidana. pelatihan ini dibekali dengan pelatih dari luar untuk menunjang proses pembinaan kemandirian. Meskipun pandemi covid-19 belum berakhir, kerjasama dengan pihak ketiga ini tetap menerapkan protokol kesehatan yang ketat demi mencegah persebaran virus corona di rutan.

Pembinaan kerajinan tangan seperti merajut dan kerajinan dari kayu. Pembinaan kemandirian berupa merajut dilakukan oleh para narapidana perempuan di Rutan Kelas I Surakarta. Pembinaan ini dilakukan tanpa adanya pendampingan pelatih akan tetapi hasil karya yang dihasilkan juga memiliki daya saing yang tinggi. Hasil karya dari merajut berupa tas berbagai macam ukuran, dompet, syal, dan lain-lain. kemudian untuk pembinaan kemandirian kerajinan dari kayu yaitu pembuatan cindera mata seperti kapal yang dibuat dari bambo. Narapidana memiliki antusias yang tinggi dalam melakukan pembuatan kerajinan ini karena setiap karya mereka dapat menarik perhatian pengunjung ketika sedang diadakan pameran.

Pembinaan kemandirian berupa sablon baju. Meskipun masih ada pandemi covid-19, pembinaan kemandirian sablon masih bertahan dalam kurun waktu yang cukup lama. Hal ini dikarenkana banyak peminat dari petugas rutan itu sendiri. Pembinaan ini dilakukan oleh beberapa narapidana laki-laki yang dibekali kemampuan mendesain gambar, pengoperasian komputer, dan dilengkapi dengan peralatan penunjang pembinaan sablon, dan bahan-bahan lainnya. Pembinaan ini diharapkan dapat membantu narapidana dalam mengembangkan kemampunan ketika sudah keluar dari rutan.

Pembinaan tersebut dapat menjadi alternatif yang dapat dilakukan di Rutan Kelas I Surakarta dimasa pandemi covid-19 saat ini. Berdasarkan hasil observasi lapangan, narapidana yang memiliki kesadaran akan pentingnya pembinaan kemandirian bagi mereka yaitu memiliki dampak yang positif seperti dapat membangun kepercayaan diri dalam 
narapidana. narapidana yang dapat mengembangkan kemampuan mereka sesuai dengan minat dan bakat maka akan dapat mengaktualisasidiri mereka untuk terus berkarya tanpa adanya paksaan dari orang lain. sehingga seseorang yang dapat mengaktualisasi diri tentu memiliki tingkat kepercayaan diri yang tinggi pula. Hal ini karena seseorang dengan rasa percaya diri yang penuh biasanya segala kebutuhan yang mereka perlukan telah terpenuhi semua seperti kebutuhan dasar atau fisiologis, kebutuhan rasa aman, kebutuhan rasa kasih sayang dan kepedulian, kebutuhan saling menghargai, dan kebutuhan untuk mengaktualisasi diri.

\section{PENUTUP}

Kesimpulan dari penelitian ini yaitu pembinaan kemandirian di Rutan Kelas I Surakarta tetap berjalan meskipun tidak efektif karena adanya pandemi covid-19. Pembinaan kemandirian yang masih berjalan dimasa pandemi covid-19 antara lain pembinaan kemandirian menjahit, sablon, dan kerajinan tangan. Seseorang yang telah terpenuhi semua kebutuan primer biasanya memiliki rasa percaya diri yang tinggi. Begitu juga dengan narapidana, narapidana yang telah terpenuhi kebutuan dasar, rasa aman, kasih sayang, saling menghargai, dan mampu mengaktualisasi diri tentu berdampak pada tingkat kepercayaan diri seseorang. Sehingga petugas perlu memfasilitasi narapidana dalam pemenuhan kebutuhan tersebut untuk membangun kembali kepercayaan diri narapidana. Sehingga petugas melakukan pemenuhan hak-hak dasar narapidana dan melakukan assesmen dalam menentukan jenis pembinaan yang disesuaikan dengan minat dan bakat agar nantinya narapidana mampu mengaktualisasi diri mereka di lingkungan masyarakat secara langsung dengan penuh rasa percaya diri. Pembinaan kemandirian alternatif yang dapat diberikan oleh Rutan Kelas I Surakarta selama adanya pandemi covid-19 diantaranya yaitu memasak, menjahit, kerajinan tangan, dan sablon baju.

\section{DAFTAR PUSTAKA}

\section{Jurnal:}

Aisharahma, H., \& Irhandayaningsih, A. (2020). Available Online at: http://ejournal.undip.ac.id/index.php/anuva Modal Sosial Sebagai Sarana Meningkatkan Rasa Percaya Diri bagi Narapidana untuk Kembali Berbaur dengan Masyarakat Abstrak. 4(4), 441-452.

Dida, S., Damayanti, T., \& Koswara, A. (2021). Representasi Indonesia pada penanganan COVID-19 di media asing. 5(2), 186-207.

Dong Y, Mo X, Hu Y, et al, 2020, Epidemiology of Covid-19 Among Children in China. American Academy of Pediatrics, DOI: 10.1542/peds.2020-0702

Equatora, M. A. (2018). Efektivitas Pembinaan Kemandirian Narapidana di Lembaga Pemasyarakatan Wirogunan Yogyakarta. EMPATI: Jurnal Ilmu Kesejahteraan Sosial, 7(1), 19-26. https://doi.org/10.15408/empati.v7i1.9648

Fitri, E., Zola, N., \& Ifdil, I. (2018). Profil Kepercayaan Diri Remaja serta Faktor-Faktor yang Mempengaruhi. 4,1-5.

Hadiwardoyo, W., Tinggi, S., Ekonomi, I., \& Barat, J. (n.d.). KERUGIAN EKONOMI NASIONAL AKIBAT PANDEMI COVID-19. 83-92. https://doi.org/10.24853/baskara.2.2.83-92

Hamanongan, J. (2018). Dua Pelaku Yang Curi Motor Dan Rudapaksa Korban Merupakan residivis. Di unduh dari http://www.tribunnews.com/metropolitan/2018/08/14/dua-pelaku- yang-curimotor-dan-rudapaksa-korban-merupakan-residivis

Kementerian Ketenagakerjaan Republik Indonesia (Kemnaker), 2020. https://finance.detik.com/beritaekonomibisnis/d-4982393/duh-nyaris-2-juta- 
pekerja-dirumahkan-dan-kena-ph

Madia, F. (2018). Rampok Nasabah Hingga Rp.714 Juta Komplotan Residivis Diringkus. Diunduh dari https://www.idntimes.com/news/indonesia/fitria-madia/rampoknasabah-hingga-rp714-juta-komplotan-residivisdiringkus/full

Nursalam, 2016, metode penelitian, \& Fallis, A. . (2013). Kedaulatan Hukum. Journal of Chemical Information and Modeling, 53(9), 1689-1699.

Saleh, S., \& Arifin, J. (2017). Pola Pemberdayaan Narapidana. Equilibrium: Jurnal Pendidikan, 3(2), 242-250. https://doi.org/10.26618/equilibrium.v3i2.449

Setiawan, H. E., \& Sakti, H. (2019). Penemuan Makna Hidup Pada Residivis Di Lembaga Pemasyarakatan Kelas 1 Semarang. Empati, 8(1), 40-48.

Sistem, S., Pidana, P., \& Negara, D. I. B. (n.d.). No Title.

\section{Buku:}

https://ebook.balitbangham.go.id/file/d2675488e1ebff1be43c1beb73277385.html $(5$ Maret 2021)

https://ebook.balitbangham.go.id/file/82b803a066122796dd316504a50a7940.html $(5$ Maret 2021 